\title{
Jerrier v Outsurance Insurance Company Limited [2015] 3 All SA 701 (KZP)
}

The duty to disclose: An ongoing problem?: Revisited

\section{Introduction}

As shown by the author in an earlier case note, (Church Jerrier $v$ Outsurance Insurance Company Ltd The duty to disclose: An ongoing problem?' 2013 De Jure 859), the case of Jerrier $v$ Outsurance Insurance Company Ltd (2013 JDR 0562 (KZP) (Jerrier a quo)) highlights the fact that the duty to disclose is still problematic. A concern highlighted in the note, was the fact, as a result of this decision, that short term insurers believed the judgment to mean that consumers are obliged to report to their insurers every minor incident, such as driving through a pothole or a scratch on their car, even where they elect not to lodge a claim for the resultant damage - failing which, their insurance claims might be rejected. This interpretation, in the opinion of the author was incorrect (an opinion now vindicated by the court of appeal).

However, since this interpretation by insurers caused a public outcry, the National Treasury stepped in. A meeting was held between Treasury, the Financial Services Board (FSB) and the South African Insurance Association (SAIA). The outcome was that SAIA declared that in future, member companies (insurers) would not reject motor car claims on the grounds that the insured did not report minor incidents. Although this was a step in the right direction, it is deemed not to be sufficient (see generally Church 2013 De Jure 859-868).

Fortunately, the decision was taken on appeal (Jerrier $v$ Outsurance Insurance Company Limited [2015] 3 All SA 701 (KZP) (Jerrier Appeal)) and 
the court, reversing the decision of the court a quo, found that the failure to disclose did not constitute 'material' non-disclosure. Thus, the fear that insurance companies could rely on this case to reject a claim where minor incidents were not disclosed (at the very least in the case of similar policies), has now been put to rest.

Be that as it may, the court of appeal, in the words of Chetty J, recognised:

how difficult it can be for a prospective client seeking insurance to determine either at the commencement of a contract or at any time thereafter, what a reasonable person would have considered to be material for the purpose of ascertaining the risk to be assumed by the insurer (par 36).

From this, it seems clear that the duty to disclose remains a concern that needs to be addressed.

\section{Facts and Judgment}

The appellant, Sherwin Jerrier (hereafter Jerrier) appealed against the judgment granted in Jerrier $v$ Outsurance Insurance Company Ltd (Jerrier a quo supra). The court a quo had dismissed Jerrier's claim against the respondent, Outsurance Insurance Company Ltd (hereafter Outsurance).

Jerrier (the plaintiff in the court a quo) had instituted action against Outsurance as a result of the company repudiating his claim for the repair of his Audi R8 damaged in a vehicle collision on 8 January 2010. The claim was founded on an insurance contract concluded between the parties. However, Outsurance denied liability, elected to reject the claim made against it, and to avoid the insurance agreement (Jerrier a quo supra at par 2). Outsurance based their defence on the fact that Jerrier had failed to comply with the provisions in the policy on two grounds.

The first related to disclosure of certain information (the so called 'non-disclosure defence'). With regard to short term insurance, where there has been a failure to disclose material information or where there has been a misrepresentation, the insurer can avoid the insurance contract or deny liability and reject the insured's claim (s 53 of the Shortterm Insurance Act 53 of 1998 (STIA)). The duty to disclose is a precontractual duty, which may become an additional or continuous duty when it is incorporated into the contract (Reinecke et al General Principles of Insurance Law (2002) par 196; Van Niekerk 'The Insured's Duties of Disclosure: Delictual and Contractual; Before the Conclusion and during the Currency of the Insurance Contract: Bruwer $v$ Nova Risk Partners Ltd' 2011 SA Merc LJ 135; Church 2013 De Jure 859).

The second related to the exclusion of cover where the insured was driving under the influence of alcohol or drugs (Jerrier a quo supra at parr $6 \& 7$ ). Although the court a quo did not deal with this defence in any great detail, it found that the evidence tendered by the defence in this regard was not admissible. Furthermore, even if it were admissible, the court reasoned that it would not be of sufficient weight to displace the 
version that Jerrier was not under the influence of alcohol Jerrier a quo supra at par 37). Consequently, it was not necessary for the court to determine whether cover would be excluded on the ground of driving under the influence. Nonetheless, Outsurance was held not to be liable on the court's interpretation of the insured's duty to disclose in the light of the circumstances of the case. In other words, even though Jerrier had had no intention of lodging a claim under the policy, his failure to report two previous incidents within the time frames stipulated in the policy, amounted to a 'material non-disclosure or breach of the terms of the policy' and this, it was held, had absolved Outsurance from liability.

On appeal, the findings of fact by the court a quo with regard to the driving under the influence, were not in issue. Consequently, the appeal centred on the finding of the court a quo with regard to non-disclosure.

The first incident, driving into a pothole (the pothole incident), occurred on 2 April 2008, prior to the conclusion of the contract. The second related to a more serious incident, a collision with a vehicle in Amamzintoti on 11 April 2009 (the Amamzintoti collision).

In the view of the court a quo, both were incidents which might have resulted in - in the sense that they could possibly have resulted in - a future claim irrespective of whether or not they did result in such claim (Jerrier a quo supra at par 29). Moreover, the court concluded that both these incidents:

would cause a reasonable man to conclude that knowledge of their occurrence would indicate a change to the plaintiff's circumstances, at the very least from a claims history perspective, but also as a moral risk, that may (not necessarily would) influence whether the defendant would give the plaintiff cover, the conditions of cover or the premium they would charge (Jerrier a quo supra at par 30).

The provisions in the policy considered by both courts provided that:

First;

In order to have cover you need to:

- pay your premiums;

- provide us with true and complete information when you apply for cover, submit a claim or make changes to your facility. This also applies when anyone else acts on your behalf;

- inform us immediately of any changes to your circumstances that may influence whether we give you cover, the conditions of cover or the premium we charge;

- E.g. If you sell your car and buy another one, you need to inform us about the change before you can take delivery of this car so that you can be certain that your car is OUTsured by the time you drive off the showroom floor.

This includes any changes to any information:

- on your schedule;

- about the financial position of any person covered under this facility, specifically relating to defaults, civil judgments, sequestrations, 
administration orders and liquidation of companies in which you have an interest;

- about convictions for offences related to dishonesty by you or any person covered under this facility (Jerrier a quo supra at par 5).

Second, the provisions determined the responsibilities of the insured in relation to the submission of claims. The insured had to report his claim or any incident that might have led to a claim to the insurer as soon as possible but not later than 30 days after any incident. This included incidents for which he did not want to claim but which might have resulted in a claim in the future (Jerrier a quo supra at par 6).

Furthermore the policy stipulated that the insured was required to provide the insurer with 'all information and documentation within the time frames' it set out and to warrant that statements made and answers given during the application for insurance and at each renewal of the contract were true and correct (Jerrier a quo supra at par 6).

Against this background, the court of appeal considered the finding of the court a quo regarding the non-disclosure defence and upheld the appeal. Contrary to the court a quo, the court of appeal followed the contextual approach taken in Mahadeo (Mahadeo $v$ Dial Direct Insurance Ltd 20084 SA $80(W)$ ). As will be discussed below, the need to establish whether non-disclosure was material in the context in which the insured found himself was emphasised.

With regard to the provisions in the contract determining time frames, the court of appeal found that the court a quo had erred in its reasoning. It had incorrectly been persuaded by the argument made by counsel for the insurer, that even where Jerrier had already himself paid the driver of the other vehicle (the third party) for his loss suffered, Outsurance would be obliged to defend or settle a claim by the third party if the third party, at a later stage, contended that he had suffered damages in excess of that amount. Counsel for Outsurance argued that such a scenario would be an example of 'an incident which may result in a claim in the future'. However, the court of appeal disagreed with this reasoning. Accordingly, it found that the words "but which may result in a claim in the future' could relate only to the election by the insured of whether or not he wished to claim beyond the 30-day period. The court noted that the "30-day notice period is a guillotine provision, after which the insurer is exempted from indemnifying the appellant or any other party which has sustained damages in an accident'. While any other party might still have a claim against the insured, the insurer would not be under an obligation to indemnify the insured against such a claim, should the insured have elected not to report the claim within the relevant time period. As no contractual nexus exists between the third party and the insurer, the words 'but which may result in a claim in the future' could only relate to the election to claim by the insured. As long as the insured had understood that where he had elected not to report the incident to the insurer, he would have had no claim against the insurer at the time 
of the incident or later - no obligation rested upon him to report the matter to the insurer.

\section{Comment}

As already stated, the duty to disclose material information is a duty that arises prior to the conclusion of the insurance contract and at each renewal. While this duty rests on both the insured and the insurer as was determined in Mutual and Federal Insurance Co Ltd $v$ Oudtshoorn Municipality (1985 1SA 419 (A)), the focus in the Jerrier case was on the insured's duty of disclosure (for an insightful evaluation of the insurer's precontractual duties see Millard \& Kuschke 'Transparency, trust and security: An evaluation of the insurer's precontractual duties' 2014 PER/ $P E L J$ 2412). The duty to disclose only becomes a continuous one if this is provided for in the contract itself. In order to establish whether or not this was so, the court had to analyse and interpret the terms of the contract as set out in the policy. The court found that it simply did not provide for this on-going duty to report after commencement of the policy (Jerrier Appeal supra at par 34). Furthermore, even if it did, the obligation to report 'incidents' was not set out with any particularity and, in the words of Chetty J, was 'bound to lead to uncertainty as to what should and should not be reported, especially where the insured had no intention of lodging a claim'. To that end, declared the judge, the appeal would be upheld (Jerrier Appeal supra at par 34). Clearly this dictum suggests that the court followed a contextual approach with regard to the interpretation of the policy and the position of the insured in this regard. The approach of the court is to be lauded.

A contextual approach would be particularly important in determining whether there was a duty on the insured to disclose and following upon this, whether non-disclosure was material. While recognising that the test for materiality is an objective test, the approach should be contextual. As Van Niekerk points out, in the application of the test, "the reasonable person has to be placed in a particular context' (Van Niekerk 'More on Insurance Misrepresentation, Materiality, Inducement and No-Claim Bonuses: Mahadeo v Dial Direct Insurance Ltd' 2008 SA Merc LJ 427). This means that the test is not what the reasonable person on the street would consider to be relevant to the assessment of the risk and premium, but what a reasonable person, in the circumstances of the particular insured, would have considered to be relevant. Various factors would have to be considered holistically in determining this. For example, not only the wording of the policy itself would be important but how it would be understood by the reasonable person in the position of the insured, against the background of the nature of the policy, how it was presented and how it would have been perceived. So too, for example, the position might be different if the agreement was concluded telephonically or where there was a broker involved. As the court of appeal noted, such a contextual approach, favoured in Mahadeo $v$ Dial Direct Insurance Ltd (supra), was not followed by the court a quo in the Jerrier a quo case (Jerrier Appeal supra at par 34). 
Various circumstances in the case under discussion were to determine whether or not the appellant had a continuous duty to disclose. In the first place, the court found that the insurer, as part of its business branding profile, prided itself on assuring prospective clients that the relevant policy documents would 'say it simply' in 'plain language' and convey details in the 'clearest possible way' and also on saving the consumer money by excluding brokers in order to reduce the premium (Jerrier Appeal supra at par 4). As was pointed out by the author in a comment on the earlier Jerrier decision, where the insured makes use of the services of a broker, the broker is obliged to warn the insured to disclose all material information and to explain what this means (Church 2013 De Jure 859; see also Reinecke et al par 474). While excluding a broker might save the insurer money, where there is no broker there is an even greater need for an insurer, as one who would understand how risk and premiums are assessed, to make sure that this is understood by a prospective insured and the policy documents should consequently be clear and comprehensible. Unfortunately, in this case - as the court pointed out - the wording of the policy was not as simple and in plain language as the insurer might have believed.

Furthermore, the premiums were to be based on an individual's profile and the policy went further to explain in plain language that 'as an insured, you are rewarded for not claiming' (Jerrier Appeal supra at par 18). Moreover, the manner in which the insurer's policy was designed, the court found, 'positively discourages its clients from submitting claims' (Jerrier Appeal supra at par 19). These facts, and the resultant uncertainty, actually reinforced the insured's perceived need to elect not to claim in the hope of preserving his 'Outbonus' and not to disclose 'incidents' where he had not claimed but self-funded damage suffered. Further to the wording of the contract and an added incentive not to submit claims, was the fact that the policy was not 'similar to other "conventional" policies, which are subject to an annual renewal' (Jerrier Appeal supra at par 20). Where a contract is subject to an annual renewal, the precontractual duty of disclosure revives and the risk will be reassessed against the insured's previous claims history and, consequently, the insurer may elect not to provide cover or to increase the premium.

A further point made by the court in regard to the contractual provisions, was that Jerrier was required to inform Outsurance immediately of any 'changes to his circumstances'. However, in the context of the wording of the policy which focussed on the financial position of the insured (for example sequestration or even a civil judgment against the insured) as affecting the risk focused on, as the court stated, envisages the insured's personal circumstances rather than a change in the condition of the vehicle (Jerrier Appeal supra at par 21). In the light of such focus, a reasonable person in the situation of the insured could have been expected to believe that it was his or her financial position that was material to the risk. Moreover, I would agree with Millard ('Jerrier v Outsurance Insurance Company Limited' 2015 Juta's 
Insurance Law Bulletin 18) that the listing of specific events would invoke the eiusdem generis rule. In terms of this rule, where a word or expression with a broad, general meaning is used in conjunction with words that denote species of the same genus, the meaning of the general word or phrase is limited to refer only to matters of the same genus (Cornelius Principles of the Interpretation of Contracts in South Africa (2002) 179). Here, 'change in circumstances' was qualified by mentioning matters that relate to the information about the insured's financial situation and not to changed circumstances pertaining to the risk or risk object. If Outsurance intended that 'change in circumstances' included the situation where the insured had himself absorbed the loss and not instituted a claim, it should have specifically stated so in the policy.

Furthermore, the court noted that the policy should not only be couched in plain language but should be clear and specific (Jerrier Appeal supra at par 22). Not only did the contract itself determine that the policy was 'a plain language document' but in respect of the terms and conditions governing the policy, the insurer undertook to " $[\mathrm{S}] \mathrm{S}$ ay it simply. There is no fine print in our documents. Our documents are easy to read and user-friendly so there are no hidden surprises"' (Jerrier Appeal supra at par 4). Despite this undertaking in the policy, the court found that the word 'incident' was vague. The duty, as contained in the policy, to disclose certain 'incidents' after the conclusion of the contract, placed an uncertain and vague burden on the insured (Jerrier Appeal supra at par 22).

The need for plain language is clear with regard to all contracts. This is so since the legal notion of consensus involves the meeting of minds of the relevant parties to the contract. Despite the fact that the Consumer Protection Act (68 of 2008) does not apply to the insurance industry (Financial Services Laws General Amendment Act s 66; see also Millard $\&$ Kuschke 2014 PER/PELJ 2412), the need for plain language is in fact recognised in the policy holder protection rules (see Policyholder Protection Rules published in terms of both the STIA and the Long-term Insurance Act 52 of 1998). However, while the need is clear and recognised in the Jerrier case, albeit in this case an obligation arising from the policy itself, it would seem that failure to use plain language would lead to costly litigation. It may be argued that standard form contracts would alleviate the problem. With tried and tested clauses in 'plain language' where the meaning of a clause became concretised over time, this would lead to legal certainty. However, this would not necessarily mean that a particular insured would comprehend the meaning and legal obligation involved.

Further to the point made above with regard to plain language, the judgment in the Court of Justice of the European Union (CJEU) in JeanClaude Van Hove v CNP Assurances SA (Case C-96/14, 23 April 2015) is apposite. The judgment, inter alia, turned on the application of Article 4(2) of the Unfair Terms in Consumer Contracts Directive of the European Union (93/13/EEC of 5 April 1993, hereafter the Directive). The 
Directive provides that consumers are not bound by unfair clauses that are set out in a contract concluded with a seller or supplier. However, terms concerned with the main subject-matter of the contract fall outside the scope of the Directive, provided that those terms are drafted in plain, intelligible language. In determining the language issue, the CJEU explained that in order to comply with the requirement, the wording 'cannot be reduced merely to their being formally and grammatically intelligible' to the consumer, but that the requirement of transparency must be interpreted broadly (Jean-Claude Van Hove supra at par 40). This would mean that besides being grammatically intelligible to the consumer, the contract must also transparently set out 'the specific functioning of the insurance arrangements, taking into account the contractual framework of which they form part, so that that consumer is in a position to evaluate, on the basis of precise, intelligible criteria, the economic consequences for him which derive from it' (Jean-Claude Van Hove supra at par 50). The sentiments expressed by the CJEU are especially relevant with regards to the drafting of contracts, particularly insurance contracts, where legal notions are not easily comprehended by the average policyholder.

Moreover, like many other commercial contracts which, as Gouws points out (Gouws 'A Consumer's Right to Disclosure and Information: Comments on the Plain Language Provisions of the Consumer Protection Act' 2010 SA Merc LJ 81), are often mass-produced and their terms nonnegotiable, so too is the case with insurance contracts. As such, the insured is not really in a position to bargain with the insurer. It is therefore gratifying that the court applied the contra proferentem rule. In terms of this rule of interpretation, where the meaning of the policy wording is ambiguous, the wording of the policy must be interpreted against the drafter of the contract, here the insurer, and in favour of the other contracting party, the insured.

\section{Conclusion}

While one may agree with the outcome of the case, and although it is gratifying that the court used a contextual approach to determine the materiality of the information to be disclosed, it is clear that it may be difficult for a court, and even more so an insured, to determine what would be considered to be material in the circumstances.

Possibly, the call by Van Niekerk for the farewell of the duty to disclose, or at least its reform (Van Niekerk 'Goodbye to the Duty of Disclosure in Insurance Law: Reasons to Rethink, Restrict, Reform or Repeal the Duty (Part 1)' 2005 SA Merc LJ 150; Van Niekerk 'Goodbye to the Duty of Disclosure in Insurance Law: Reasons to Rethink, Restrict, Reform or Repeal the Duty (Part 2)' 2005 SA Merc LJ 323), still rings true, especially in the current era of consumer protection. However, crucial to the contract of insurance is the need for both the insurer and the insured to comprehend the risk-based approach. 
What has been said in an earlier publication bears repeating (see Church 2013 De Jure 859). While it may be so that certain knowledge could exclusively be within the insured's domain, and that the insurer may need to rely on the disclosure of such information, it would be the insurer who is generally in a better position to know how a specific risk is assessed and the premium determined. The risks that the insured offers for insurance are very often assessed and the premium determined according to categories - all risks that fall into a certain profile are then rated in the same way. Especially with regard to certain types of policies, such as motor vehicle policies, the insurer would know what the categories are and what the risk and rating factors would be. Specifically with regards to the type of policy in casu, and one where a 'no claim bonus' is applicable, the insurer would be in the best position to explain the risk-based approach and to ask the relevant questions in order to alert the insured to what information was required. In the Jerrier case for example, the actuary's testimony as to what would result in an adjustment in premium and acceptance of the risk, could briefly be summarised in one paragraph.

Particularly where there is a continuous contractual duty to disclose in the case of a short-term insurance policy, it would be the insurer who would comprehend the principles underpinning a 'no-claim bonus'. It would be the insurer who would understand why such continuous duty to disclose would be relevant in the specific circumstances. It should therefore be incumbent upon the insurer to communicate this clearly to the insured. This would be fair and in the interest of both the insured and the insurer. 